Наносистели, нанолатеріали, нанотехнології Nanosistemi, Nanomateriali, Nanotehnologii 2019, т. 17, № 3, сc. 439-452 (c) 2019 IМФ (Інститут металофізики ім. Г. В. Курдюмова НАН України) Надруковано в Україні. Фотокопіювання дозволено тільки відповідно до ліцензії

PACSnumbers: 68.37.Hk, 68.43.Mn, 68.43.Nr, 78.30.Hv, 81.70.Pg, 82.33.Jx, 82.75.-z

\title{
Utilisation of Fly Ash and Magnetite for the Synthesis of Biosurfactant-Modified Magnetic Zeolites by Direct Alkali Fusion
}

\section{Olusola S. Amodu ${ }^{1}$, Tunde V. Ojumu ${ }^{2}$, Seteno K. Ntwampe ${ }^{3}$,} and Olushola S. Ayanda ${ }^{4}$

\author{
${ }^{1}$ Department of Chemical Engineering, \\ Lagos State Polytechnic, \\ P.M.B. 21606, \\ Lagos, Nigeria \\ ${ }^{2}$ Department of Chemical Engineering, \\ Cape Peninsula University of Technology, \\ P.O. Box 962 \\ Cape Town, South Africa \\ ${ }^{3}$ Department of Biotechnology, \\ Cape Peninsula University of Technology, \\ P.O. Box 962, \\ Cape Town, South Africa \\ ${ }^{4}$ Department of Chemistry, \\ Federal University Oye Ekiti, \\ Ekiti State, Nigeria
}

This work presents the synthesis of zeolite (Z), magnetic zeolite (MZ) and biosurfactant-modified magnetic zeolite (BMMZ) by direct fusion of sodium hydroxide, coal fly ash, and magnetite. The precursors and the synthesised zeolites were characterised by scanning electron microscopy (SEM) equipped with an energy dispersive spectroscopy (EDS), thermogravimetric analysis (TGA), Fourier transform infrared spectroscopy (FTIR), X-ray diffraction (XRD), and Brunauer, Emmett and Teller (BET) surface area analyser. The SEM analysis of $\mathrm{Z}$ and BMMZ showed the presence of distinct nanocube structures, while the MZ showed aggregated irregular surfaces with crevices at the surface. XRD indicated that the fly ash consists of sillimanite, quartz and mullite, the sodalite in $\mathrm{Z}, \mathrm{MZ}$ and $\mathrm{BMMZ}$ as indicative of $\mathrm{NaOH}$ used in the preparation of the zeolites. The EDS analysis based on the $\mathrm{Si} / \mathrm{Al}$ classification showed that zeolite $\mathrm{X}$ was produced. The functional group signified asymmetric and symmetric stretching vibrations of $\mathrm{O}-\mathrm{H}$ and internal tetrahedron vibrations of $\mathrm{Si}-\mathrm{O}$ and $\mathrm{Al}-\mathrm{O}$. The modification of the surface of $\mathrm{Z}$ with biosurfactant increased the BET surface area by $56.2 \%$ in comparison to 
the unmodified Z. Therefore, the synthesised Z, MZ and BMMZ would be effective for the removal of organic contaminants, owing to excellent and improved properties.

У даній роботі представлено синтезу цеоліту (Z), магнетного цеоліту (MZ) та модифікованого біосурфактантом магнетного цеоліту (BMMZ) шляхом прямої синтези гідроксиду натрію, вугільної летючої золи та магнетиту. Попередники та синтезовані цеоліти було охарактеризовано за допомогою сканувальної електронної мікроскопії (CEM), забезпеченої енергодисперсійною спектроскопією (ЕДС), термогравіметричною аналізою (ТІА), інфрачервоною спектроскопією з Фур'є-перетвором (ФПІЧ), Рентгеновою дифракцією (РД) й аналізатором площі поверхні за БрунауеромЕмметтом-Теллером (БЕТ). CEM-аналіза Z і BMMZ показала наявність різних структур нанокубів, в той час як MZ проявив агреговані нерівні поверхні з тріщинками на поверхні. Рентгенограма показала, що попільний пил складається з силіманіту, кварцу та муліту, содаліту в Z, MZ i $\mathrm{BMMZ}$ як показника $\mathrm{NaOH}$, використовуваного при одержанні цеолітів. ЕДС-аналіза, заснована на класифікації $\mathrm{Si} / \mathrm{Al}$, показала, що був одержаний цеоліт X. Функціональна група означала асиметричні та симетричні валентні коливання $\mathrm{O}-\mathrm{H}$ і внутрішні тетраедричні коливання $\mathrm{Si}-\mathrm{O}$ й $\mathrm{Al}-$ O. Модифікація поверхні Z біосурфактантом збільшила площу поверхні за БЕТ на 56,2\% у порівнянні з немодифікованим Z. Отже, синтезовані Z, MZ і BMMZ були б ефективними для видалення органічних забруднень завдяки чудовим і поліпшеним властивостям.

В данной работе представлен синтез цеолита (Z), магнитного цеолита (MZ) и модифицированного биосурфактантом магнитного цеолита (BMMZ) путём прямого синтеза гидроксида натрия, угольной летучей золы и магнетита. Предшественники и синтезированные цеолиты были охарактеризованы с помощью сканирующей электронной микроскопии (СЭМ), снабжённой энергодисперсионной спектроскопией (ЭДС), термогравиметрическим анализом (ТГА), инфракрасной спектроскопией с фурьепреобразованием (ФТИК), рентгеновской дифракцией (РД) и анализатором площади поверхности по Брунауэру-Эммету-Теллеру (БЭТ). СЭМанализ Z и BMMZ показал наличие различных структур нанокубов, в то время как MZ показал агрегированные неровные поверхности с трещинами на поверхности. Рентгенограмма показала, что зольная пыль состоит из силлиманита, кварца и муллита, содалита в Z, MZ и BMMZ в качестве показателя $\mathrm{NaOH}$, используемого при получении цеолитов. ЭДС-анализ, основанный на классификации $\mathrm{Si} / \mathrm{Al}$, показал, что был получен цеолит $\mathrm{X}$. Функциональная группа означала асимметричные и симметричные валентные колебания $\mathrm{O}-\mathrm{H}$ и внутренние тетраэдрические колебания $\mathrm{Si}-\mathrm{O}$ и $\mathrm{Al}-\mathrm{O}$. Модификация поверхности $\mathrm{Z}$ биосурфактантом увеличила площадь поверхности по БЭТ на $56,2 \%$ по сравнению с немодифицированным $\mathrm{Z}$. Следовательно, синтезированные Z, MZ и BMMZ были бы эффективными для удаления органических загрязнений благодаря превосходным и улучшенным свойствам.

Key words: adsorbent, biosurfactant-modified zeolite, characterisation, magnetite, nanoparticles. 
Ключові слова: адсорбент, модифікований біосурфактантом цеоліт, характеризація, магнетит, наночастинки.

Ключевые слова: адсорбент, модифицированный биосурфактантом цеолит, характеризация, магнетит, наночастицы.

(Received 14 May, 2019)

\section{INTRODUCTION}

Zeolites are inorganic crystalline aluminosilicates; they are categorised as microporous materials [1] and are valuable in catalytic cracking, waste management, cation exchanger, gas dryer and adsorption. Zeolites have the properties of excellent ion exchange capacities, high selectivity, high catalytic properties, and easy regeneration without losing their adsorption capacities [2, 3]. Consequently, zeolites have received more attention, particularly, for the removal of oily contaminants [4-6]. The discovery of a good precursor such as fly ash (FA) for the synthesis of zeolites with magnetic properties has enhanced the application of zeolites for the adsorption of hydrocarbon contaminants [7-10]. However, since zeolites are hydrophilic and do not have large adsorption capacities for hydrophobic organic compounds, their applications for the removal of hydrophobic contaminants may be a challenge. Nonetheless, adsorption-dependent parameters such as $\mathrm{Si} / \mathrm{Al}$ ratio, including cation type, number and location of cation on the zeolites surface, are often manipulated to improve the adsorption efficiency of zeolites for hydrophobic compounds. One of such treatment methods is the use of surfactant modification by ion-exchange mechanisms [5]. In addition, surfactant modification of zeolites is influenced by hydrophobic effects and cation exchange, whereby the positive moieties of cationic surfactants are readily exchanged with the replaceable cations on the external surface of the zeolites, forming surfactant layers [11]. The modification process allows for the exchangeable cations on zeolites surface to be replaced with cations from the surfactant molecule. The commonly used surfactants are the quaternary ammonium compounds, for example, hexadecyltrimethyl ammonium bromide, with cationic head groups and a hydrocarbon long-chain molecule as the surfactant tail [5, 12-14]. Thus, the zeolite surface becomes hydrophobic that allows the adsorbent to retain organic compounds [15].

Although an array of contaminants such as anions, cations, and organics-phenol, 4-chlorophenol, orange II, bisphenol A, and sodium dodecyl benzene sulfonate have been reportedly removed by surfactantmodified zeolites (SMZ) from aqueous solution [9, 15-19], however, the environmental friendliness of the nanocomposite still raises concerns. Hence, modification with environmentally benign surface- 
active agents (biosurfactants), rather than with chemical surfactant, is necessary to sustain the novel technology.

The objectives of this research were as follow: synthesis of zeolite (Z) and magnetic zeolite (MZ) from FA (a low-cost precursor produced as waste from coal fired plants); modification of the synthesised $\mathrm{Z}$ with biosurfactant produced from Beta vulgaris waste; and finally, characterization of the precursors and the synthesised zeolites by modern analytical techniques.

\section{MATERIALS AND METHOD}

\subsection{Coal Fly Ash and Chemical Reagents}

The coal FA used in the present study was obtained from a coal-fired plant in Gauteng, South Africa. Sodium hydroxide $(\mathrm{NaOH})$ and anhydrous sodium aluminate were obtained from Sigma-Aldrich, while the magnetite nanoparticles $\left(\mathrm{Fe}_{3} \mathrm{O}_{4}\right)$ were obtained from Merck. The biosurfactant used was produced by Bacillus licheniformis STK 01 and characterised as reported in our previous study [20].

\subsection{Synthesis of Zeolite and Nanocomposite}

Magnetic zeolite (MZ) was synthesized, in a batch system, by direct fusion of $\mathrm{FA}, \mathrm{NaOH}$, and $\mathrm{Fe}_{3} \mathrm{O}_{4}$, in a ratio of 1:1.5:y, in grams, respectively, where $y$ represents $0.1,0.2,0.3,0.5$, and 0.75 . Zeolite $(\mathrm{Z})$, without the addition of magnetite particles, was also synthesized from the FA. The optimized ratio of $\mathrm{FA}$ and $\mathrm{NaOH}$ combination has been reported earlier [21, 22]. Since the magnetite ratio can influence the affinity of the nanocomposite for the hydrocarbon contaminants, the quantity used was varied. The resultant magnetic zeolites were designated MZ1, MZ2, MZ3, MZ4, and MZ5, while the respective biosurfactant-modified magnetic zeolites (BMMZ) were represented as BMMZ1, BMMZ2, BMMZ3, BMMZ4, and BMMZ5. The combination of the precursor that gave the highest adsorption was found to be 1:1.5:0.3 (in grams), for $\mathrm{FA}, \mathrm{NaOH}$, and $\mathrm{Fe}_{3} \mathrm{O}_{4}$, respectively, based on the preliminary experiments on naphthalene adsorption (results not shown). Hence, MZ3 and BMMZ3 were shown to be better adsorbents and, as such, they were characterized.

\subsubsection{Magnetic Zeolite Synthesis}

The raw FA samples were screened through a $212 \mu \mathrm{m}$ sieve to eliminate larger particles. A mixture of $\mathrm{NaOH}, \mathrm{FA}$, and $\mathrm{Fe}_{3} \mathrm{O}_{4}$ in a predetermined ratio of 1:1.5:y (by weight), respectively, was milled and fused in an ov- 
en at a temperature of $550^{\circ} \mathrm{C}$ for $1 \frac{1}{2} \mathrm{~h}[20,21]$. The quantity of magnetite $(y)$ in this composite varied from 0.1-0.75. The resultant fused MZ was then cooled to ambient temperature, milled further, and dissolved in distilled water $(1 \mathrm{~g} / 5 \mathrm{~mL}$ water $)$. The slurry obtained was stirred at $1500 \mathrm{rpm}$ and at room temperature for $2 \mathrm{~h}$. The resultant precipitate was filtered and washed repeatedly with distilled water to remove the remaining solids. Thus, the filtrate obtained was mixed with $\mathrm{NaAlO}_{2}(\mathrm{aq})$ in a ratio of 2.5:1 $(v / v)$, stirred for 20 min and crystallized at $100^{\circ} \mathrm{C}$ for $2-4 \mathrm{~h}$. The purpose of the addition of the aluminate solution was to control the molar ratio for single-phase $\mathrm{Z}$ synthesis.

\subsubsection{Modification of Zeolite with Biosurfactant}

Twenty-five (25) grams of the synthesized MZ was mixed with $0.5 \mathrm{~L}$ of biosurfactant solution. The mixture of the MZ and the biosurfactant solution was stirred for $7 \mathrm{~h}$ at $100 \mathrm{rpm}$ at ambient temperature of $25^{\circ} \mathrm{C}$. The suspension formed was filtered and oven dried at $70^{\circ} \mathrm{C}$ for $10 \mathrm{~h}$.

\subsection{Characterization}

\subsubsection{Morphological Studies}

For the morphological studies, samples were sprinkled on a special glue, mixed with carbon graphite and mounted on an aluminium stub, and analysed with a S200 scanning electron microscope (SEM) equipped with an energy dispersive x-ray spectroscopy (EDS) to determine the elemental composition of the samples.

\subsubsection{X-Ray Diffraction}

Mineralogical determination of the synthesized zeolites and fly ash was carried out by a Bruker D8 Advance X-Ray Diffractometer (Bruker Corporation, Germany) equipped with a Co source and a Vantec position-sensitive detector. Powder x-ray diffraction (XRD) patterns were collected within the 2 -theta range of 5 and $70^{\circ}$, with a step size of $0.0062^{\circ}$, and a step time of $360 \mathrm{~s}$ under continuous rotation of the sample during the scan. The identification of the mineral composition and phases in the samples were carried out using MATCH-a commercial software for phase identification.

\subsubsection{FTIR}

The different functional groups and bonds present in the crystal sam- 
ples were examined using a Fourier transform infrared (FTIR) spectrophotometer (PerkinElmer Ltd, UK). The crystalized samples of zeolites and the powdered sample of FA were prepared for FTIR assays by milling the extracts with $\mathrm{KBr}$ subsequent to pressing with an $8,000-\mathrm{kg}$ load (Specac Bench-Top Hydraulic Presses) for 20 min to form a thin wafer. IR spectra were monitored from 400 to $4000\left(\mathrm{~cm}^{-1}\right)$ wave numbers. Spectra showing the functional groups were used to study the composition of the biosurfactant. Absorption spectra were plotted using a built-in plotter, while the $\mathrm{KBr}$ disk was used as a background reference.

\subsubsection{Thermogravimetric Analysis}

Thermogravimetric analysis (TGA) was performed using a Mettler Toledo TGA-DSC 1 analyser. The experiment was carried out using nitrogen as a purge gas in the temperature range from ambient to $800^{\circ} \mathrm{C}$, with a heating rate of $10^{\circ} \mathrm{C} / \mathrm{min}$ and an inert gas flow rate of 70 $\mathrm{mL} / \mathrm{min}$.

\subsubsection{BET Surface Area Determination}

For the Brunauer-Emmett-Teller (BET) surface area determination, samples were degassed prior to analysis at $90^{\circ} \mathrm{C}$ for $60 \mathrm{~min}$, thereafter at $250^{\circ} \mathrm{C}$ for $12 \mathrm{~h}$, using a Micromeritics VacPrep ${ }^{\circledR} 061$ Sample Degas System (Micromeritics, USA), while a 3Flex surface characterization analyser (Micromeritics Instrument Corp., USA) was used. To determine the surface area, the temperature of the degassed samples was first reduced to that of liquid nitrogen. Then, the absorbing gas (nitrogen) was admitted in incremental doses. The accumulated gas quantity adsorbed versus gas pressure data at one temperature were then plotted to generate an adsorption isotherm using the Barrett-JoynerHalenda (BJH) method. The data obtained were treated in accordance with the BET gas adsorption method to calculate the specific surface areas for the sample in units of square meters per gram.

\section{RESULTS AND DISCUSSION}

\subsection{Morphology, Phase and FTIR Characterization}

The morphology and crystallographic examination of the synthesized Z and BMMZ using SEM, at 5000 $\times$ magnification, showed distinct nanocube structures, while the MZ revealed aggregated irregular surfaces on a $20 \mu \mathrm{m}$ scale (Fig. 1). The FA is spherical, and the surfaces indicated the presence of occluded $\mathrm{OH}^{-}$condensate and very few amor- 


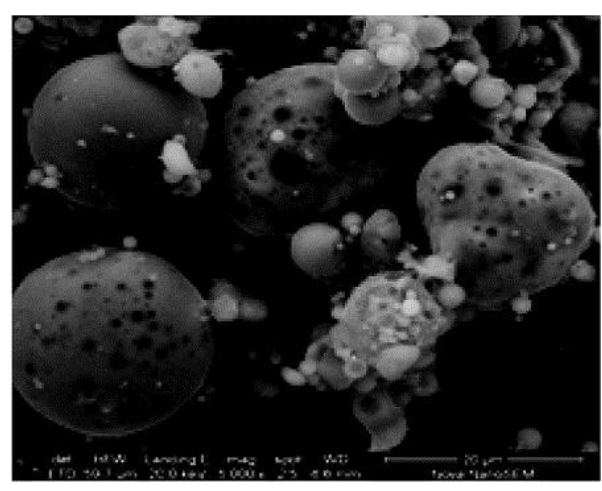

$a$

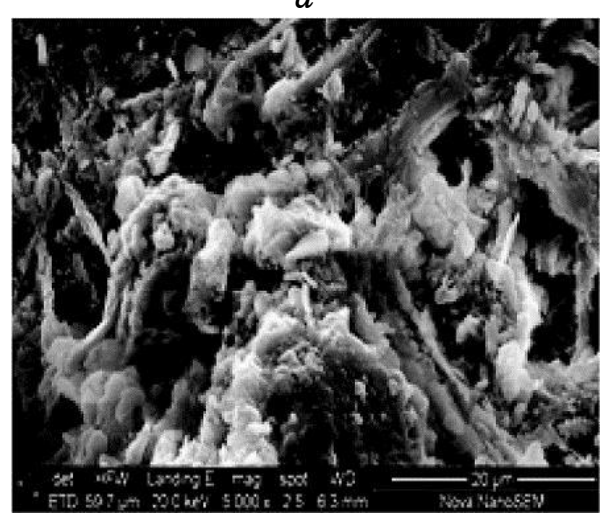

c

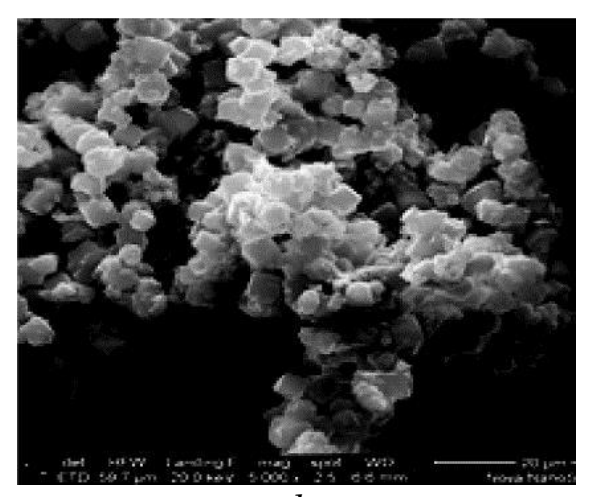

$b$

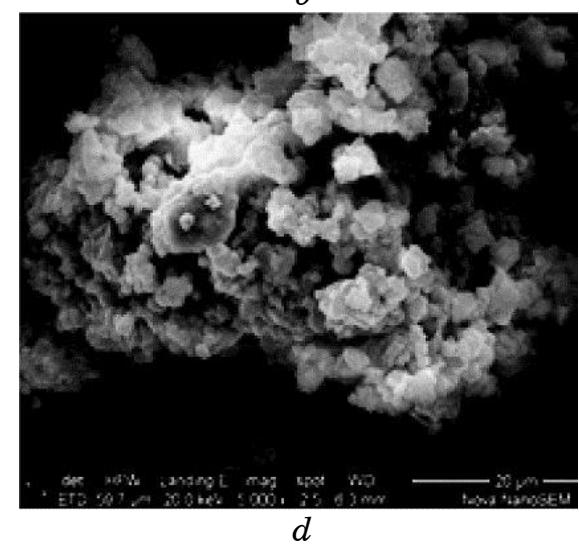

Fig. 1. Scanning electron micrographs of fly ash $(a)$, zeolite $(b)$, magnetic zeolite $(c)$, and biosurfactant-modified magnetic zeolite $(d)$.

phous carbon.

The phase identification of the zeolites and FA by XRD revealed that the samples are crystalline. The peaks observed are similar to those often reported for zeolites synthesized from FA as containing basically sillimanite, quartz and mullite (Fig. 2). The most predominant peak for FA, which occurred at $2 \Theta$ of $30^{\circ}$, is often due to the presence of quartzite mineral $[22,23]$. The presence of sodalite in $\mathrm{Z}, \mathrm{MZ}$ and BMMZ resulted from the use of $\mathrm{NaOH}$ to synthesise these samples. The phases matched in the diffraction pattern and their relative percentage contributions are presented in Table 1.

The FTIR spectra of $\mathrm{Z}$ and MZ, represented in Fig. 3, showed highest bands from $3457 \mathrm{~cm}^{-1}$ to $3415 \mathrm{~cm}^{-1}$, which signified asymmetric and symmetric stretching vibrations of $\mathrm{O}-\mathrm{H}$. Bands between $453 \mathrm{~cm}^{-1}$ and $465 \mathrm{~cm}^{-1}$ represented internal tetrahedron vibrations of $\mathrm{Si}-\mathrm{O}$ and $\mathrm{Al}-$ $\mathrm{O}, 1450 \mathrm{~cm}^{-1}$ and $866 \mathrm{~cm}^{-1}$ denoted $\mathrm{Z}$ formation, while band at 1449 $\mathrm{cm}^{-1}$ is an $\mathrm{O}-\mathrm{H}$ bending mode. 


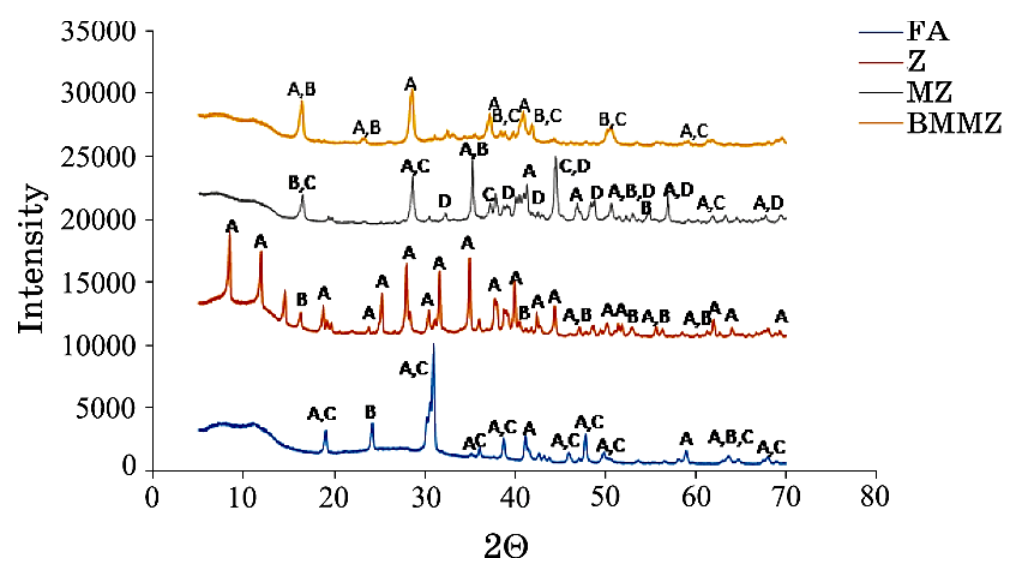

Fig. 2. XRD diffraction pattern of fly ash, zeolite, magnetic zeolite, and biosurfactant-modified magnetic zeolite.

TABLE 1. Phases matched in the diffraction pattern and their relative percentage contributions.

\begin{tabular}{|c|c|c|c|c|}
\hline 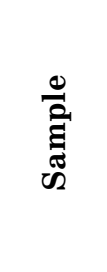 & 宏 & Phase & 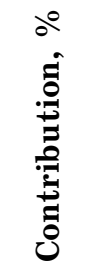 & Empirical Formula \\
\hline \multirow{3}{*}{ FA } & $\mathrm{A}$ & Sillimanite & 85.3 & $\mathrm{Al}_{2} \mathrm{O}_{5} \mathrm{Si}$ \\
\hline & B & $\begin{array}{c}\text { Silicon oxide } \\
\text { (\$-beta Quartz high) }\end{array}$ & 13.9 & $\mathrm{O}_{2} \mathrm{Si}$ \\
\hline & $\mathrm{C}$ & Mullite & 0.7 & $\mathrm{Al}_{2.25} \mathrm{O}_{4.871} \mathrm{Si}_{0.75}$ \\
\hline \multirow{2}{*}{$\mathrm{Z}$} & $\mathrm{A}$ & $\mathrm{Na}_{35.4} \mathrm{~K}_{60} \mathrm{Al}_{95.44} \mathrm{Si}_{96.6} \mathrm{O}_{384}$ & 80.1 & $\mathrm{Al}_{95.44} \mathrm{~K}_{60} \mathrm{Na}_{35.4} \mathrm{O}_{384} \mathrm{Si}_{96.6}$ \\
\hline & $\mathrm{B}$ & Sodalite & 19.9 & $\mathrm{Al}_{3} \mathrm{ClNa}_{4} \mathrm{O}_{12} \mathrm{Si}_{3}$ \\
\hline \multirow{4}{*}{$\mathrm{MZ}$} & A & Jadeite & 35.8 & $\mathrm{Al}_{0.52} \mathrm{Ca}_{0.47} \mathrm{Fe}_{0.48} \mathrm{Na}_{0.53} \mathrm{O}_{6} \mathrm{Si}_{2}$ \\
\hline & $\mathrm{B}$ & Omphacite & 26.7 & $\mathrm{Al}_{0.758} \mathrm{Ca}_{0.286} \mathrm{Fe}_{0.082} \mathrm{Mg}_{0.205} \mathrm{Na}_{0.602} \mathrm{O}_{6} \mathrm{Si}_{2}$ \\
\hline & $\mathrm{C}$ & Sodalite & 24.8 & $\mathrm{Al}_{3} \mathrm{ClFe}_{0.04} \mathrm{Na}_{3.76} \mathrm{O}_{12} \mathrm{Si}_{3}$ \\
\hline & $\mathrm{D}$ & Wonesite & 12.7 & $\mathrm{Al}_{0.8} \mathrm{Fe}_{0.42} \mathrm{Mg}_{2.58} \mathrm{Na}_{0.55} \mathrm{O}_{12} \mathrm{Si}_{3.2}$ \\
\hline & A & Sodalite & 83.4 & $\mathrm{Al}_{3} \mathrm{ClFe}_{0.04} \mathrm{Na}_{3.76} \mathrm{O}_{12} \mathrm{Si}_{3}$ \\
\hline \multirow{2}{*}{ BMMZ } & $\mathrm{B}$ & Mordenite & 10.9 & $\mathrm{Al}_{1.85} \mathrm{Fe}_{0.007} \mathrm{H}_{10.002} \mathrm{Na}_{0.547} \mathrm{O}_{25.568} \mathrm{Si}_{10.133}$ \\
\hline & $\mathrm{C}$ & $\mathrm{Fe}_{2.7} \mathrm{Na}_{2}\left(\mathrm{Si}_{12} \mathrm{Al}_{12} \mathrm{O}_{48}\right) \cdot\left(\mathrm{H}_{2} \mathrm{O}\right)_{14.8}$ & 5.6 & $\mathrm{Al}_{12} \mathrm{Fe}_{2.7} \mathrm{H}_{29.6} \mathrm{Na}_{2} \mathrm{O}_{62.8} \mathrm{Si}_{12}$ \\
\hline
\end{tabular}

The shifting of $\mathrm{Si}-\mathrm{O}$ or $\mathrm{Al}-\mathrm{O}$ band was signified at $1096 \mathrm{~cm}^{-1}$, with stretching vibrations to lower frequencies at $984 \mathrm{~cm}^{-1}$ as shown for Z and BMMZ. In addition, the weak bands at $1646 \mathrm{~cm}^{-1}$ and $1651 \mathrm{~cm}^{-1}$ are 


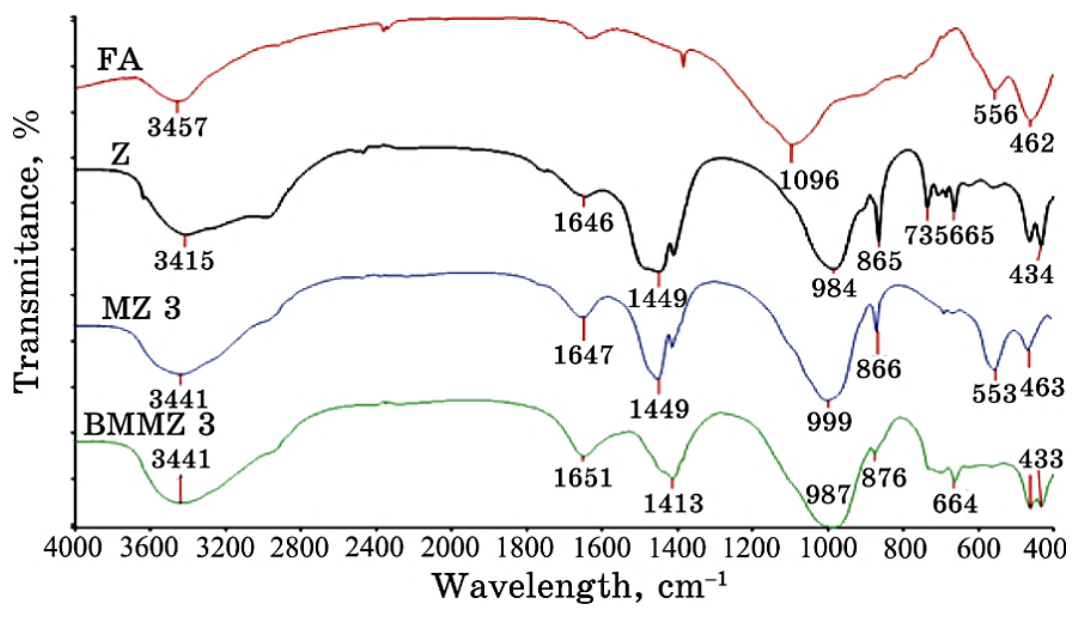

Fig. 3. FTIR spectra of fly ash, zeolite, magnetic zeolite, and biosurfactant-modified magnetic zeolite.

attributed to the bending mode of $\mathrm{H}_{2} \mathrm{O}$ molecules. The shifting of $\mathrm{Si}-\mathrm{O}$ or $\mathrm{Al}-\mathrm{O}$ at $1096 \mathrm{~cm}^{-1}$ appears to be more conspicuous in FA.

\subsection{TGA Analysis and Energy Dispersive X-Ray Spectroscopy}

The TGA was performed to assess the thermal stability of the zeolites. The mass change observed as temperature changed from 22 to $795^{\circ} \mathrm{C}$ was due to the evaporation of volatiles such as water.

The TGA analysis revealed a weight loss, which accounts for about $20 \%$ of the original weight for both $\mathrm{Z}$ and BMMZ tested (Fig. 4). The weight loss for the samples occurred in two stages - the evaporation of the more volatile fractions, which is often ascribed to the evaporation of the $\mathrm{OH}^{-}$condensate, was observed from 22 to $200^{\circ} \mathrm{C}$, followed by the evaporation of the less volatile fractions, usually occluded hydrocarbon compounds. Typically, the evaporation of strongly adsorbed fractions within the intrapores of the zeolites occurs at a relatively higher temperature. A similar trend had been reported earlier [24].

The elemental distribution of the samples was assessed with EDS. As shown in Table 2, the increase in the Fe content of the MZ may obviously be due to the presence of $\mathrm{Fe}^{2+} / \mathrm{Fe}^{3+}$ of the magnetite particles. Furthermore, according to the International Zeolite Association (IZA) and the International Mineralogical Association (IMA), zeolites with a $\mathrm{Si} / \mathrm{Al}$ ratio of 1-1.5, in their framework, are classified as zeolite $\mathrm{X}$ [25-27]. Thus, a $\mathrm{Si} / \mathrm{Al}$ ratio of 1.2, obtained from the EDS analysis, showed that the synthesized $\mathrm{Z}$ is zeolite $\mathrm{X}$ with pore sizes ranging from $0.45-0.80 \mathrm{~nm}$. 


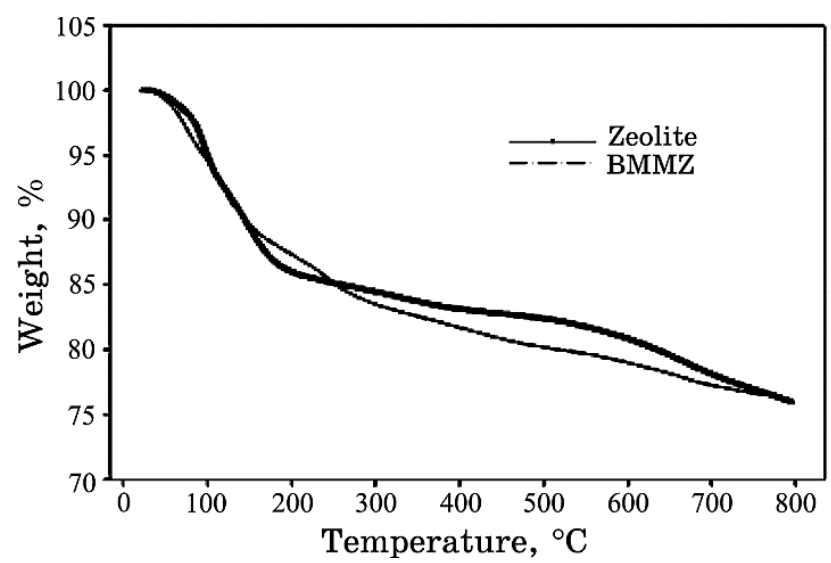

Fig. 4. Thermogravimetric analysis of zeolite and biosurfactant-modified magnetic zeolite.

TABLE 2. EDS analysis of fly ash, zeolite, magnetic zeolite, and biosurfactant-modified magnetic zeolite.

\begin{tabular}{c|c|c|c|c}
\hline Chemical Element & FA & Z & MZ & BMMZ \\
\hline $\mathrm{C}$ & 34.40 & 22.55 & 20.68 & - \\
$\mathrm{O}$ & 46.63 & 46.38 & 46.19 & 45.48 \\
$\mathrm{Na}$ & - & 9.97 & 23.83 & 14.13 \\
$\mathrm{Al}$ & 4.44 & 8.78 & 3.19 & 11.74 \\
$\mathrm{Si}$ & 19.04 & 10.44 & 3.09 & 16.07 \\
$\mathrm{Ca}$ & 2.25 & 1.29 & 0.22 & 1.50 \\
$\mathrm{Fe}$ & - & 0.59 & 2.80 & 9.69 \\
$\mathrm{~K}$ & - & - & - & 1.38 \\
\hline
\end{tabular}

\section{3. $\mathrm{N}_{2}$ Adsorption}

Typical $\mathrm{N}_{2}$ adsorption/desorption isotherms for the synthesized Z, MZ, and BMMZ are shown in Fig. 5. Further, to understand the adsorption capacity of the synthesized zeolites, a $t$-plot was generated using Eq. (1) proposed by Harkins-Jura to determine the micropore volume $\left(V_{m i c}\right)$ and mesopore volume $\left(V_{\text {mes }}\right)$ as well as the external surface area:

$$
t=\left[13.99 /\left(0.034-\log \left(P / P_{0}\right)\right)\right]^{0.5} .
$$

The $V_{\text {mic }}$ and $V_{\text {mes }}$ were obtained from the intercepts of the curves with the $y$-axis, with the thickness range from $3.5 \AA$ to $6 \AA$. Moreover, the BET and Langmuir surface areas were determined for the zeolites by 

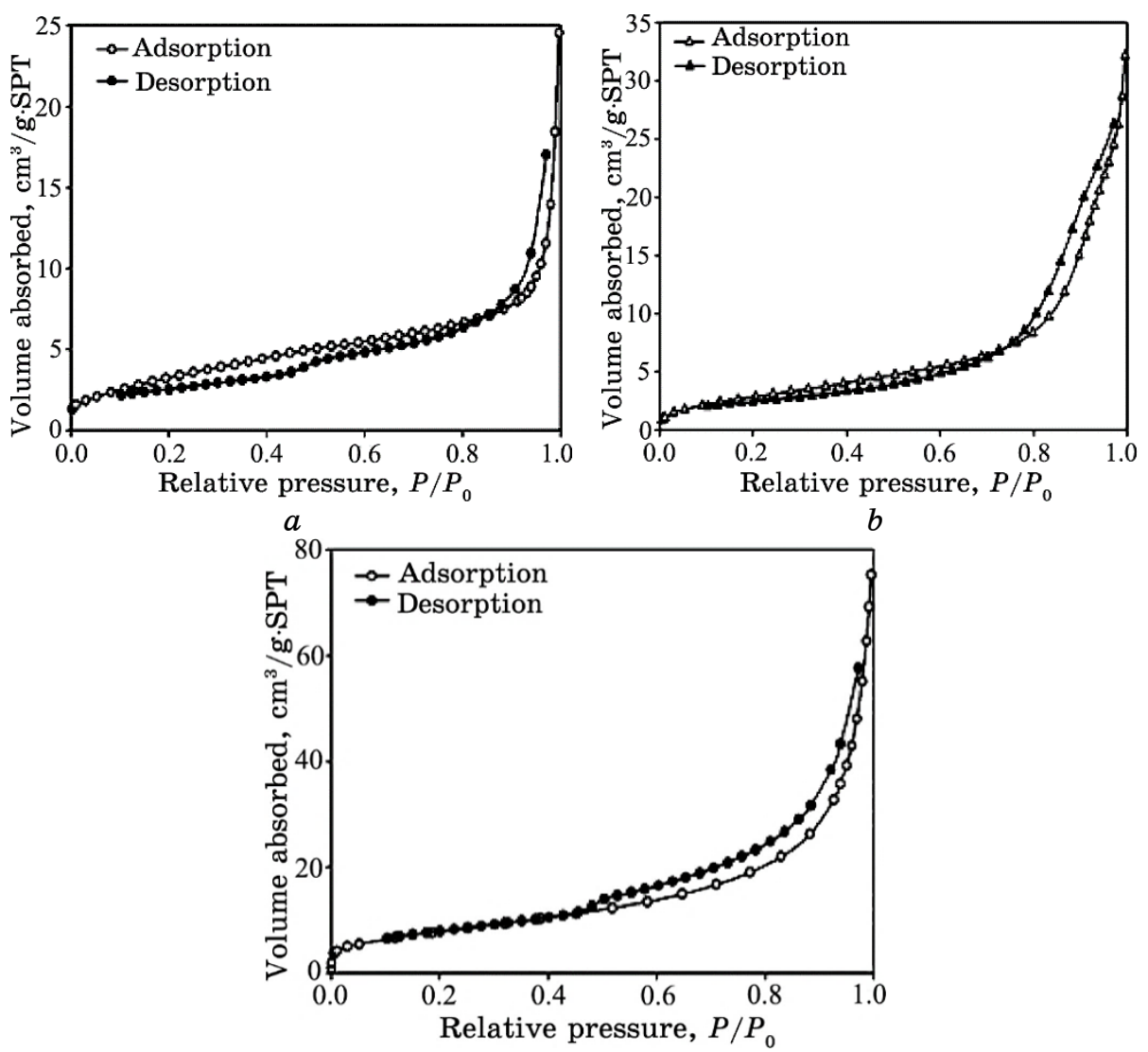

$c$

Fig. 5. Nitrogen adsorption isotherms of zeolite $(a)$, magnetic zeolite $(b)$, and biosurfactant-modified magnetic zeolite $(c)$.

measuring the amount of $\mathrm{N}_{2}$ adsorbed at different relative pressures.

The $\mathrm{N}_{2}$ adsorption isotherms obtained for the synthesised $\mathrm{Z}$ (Fig. 5) showed a type- $4 H$ hysteresis loop as characterized by the IUPAC, which is often associated with slit-shaped pores-the type that is mainly obtained with activated carbons [28]. This hysteresis loop resulted from capillary condensation in the mesopores. Considering that this type of loop does not peak at $P / P_{0}$, it was difficult to establish the limiting boundary of the desorption curve. The adsorption of $\mathrm{N}_{2}$ onto the zeolites was generally slow that, for $\mathrm{Z}$, about $70 \%$ of the gas was adsorbed at $P / P_{0}$ between 0.9 and 1.0 . Similarly, for $\mathrm{MZ}$, about $78 \%$ of the pores were covered at $P / P_{0}$ between 0.8 and 1.0 , while for the BMMZ only about $30 \%$ of the sorption capacity was used up to $P / P_{0}$ of 0.8 . The slow rate of adsorption observed was due to the unexpectedly low BET surface area determined for these nanoparticles (Table 3). 
TABLE 3. BET analysis of fly ash, zeolite, magnetic zeolite, and biosurfactant-modified magnetic zeolite.

\begin{tabular}{c|c|c|c|c}
\hline Parameters & FA & Z & MZ & BMMZ \\
\hline$S_{\mathrm{BET}}, \mathrm{m}^{2} \cdot \mathrm{g}^{-1}$ & 6.05 & 12.56 & 11.16 & 28.68 \\
$S_{\mathrm{L}}, \mathrm{m}^{2} \cdot \mathrm{g}^{-1}$ & 27.00 & 46.78 & 48.73 & 125.52 \\
$S_{\mathrm{EXT}}, \mathrm{m}^{2} \cdot \mathrm{g}^{-1}$ & 7.44 & 14.92 & 14.47 & 31.35 \\
Average pore diameter, $\AA$ & 58.19 & 121.17 & 178.70 & 162.51 \\
$V_{\text {mic }}, \mathrm{cm}^{3} \cdot \mathrm{g}^{-1}$ & 0.0007 & 0.0015 & 0.0018 & 0.0015 \\
\hline
\end{tabular}

Note: $S_{\mathrm{BET}}-\mathrm{BET}$ surface area, $S_{\mathrm{L}}$-Langmuir surface area; $V_{m i c}$-micropore volume; $S_{\mathrm{EXT}}-$ external surface area.
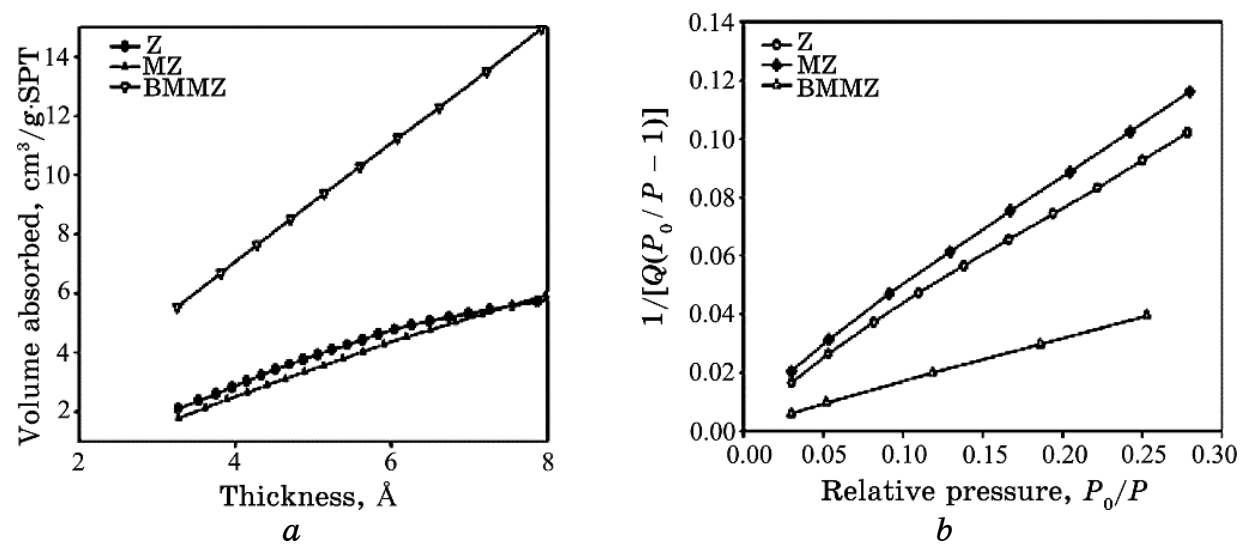

Fig. 6. The $t$-plots $(a)$ and BET surface area plots $(b)$ for zeolite, magnetic zeolite, and biosurfactant-modified magnetic zeolite.

However, it is remarkable to note that the modification of $\mathrm{Z}$ with biosurfactant increased the surface area by $56.2 \%$. Furthermore, $\mathrm{N}_{2}$ adsorption increased with respect to increased surface area, with BMMZ recording the highest adsorption of $75.21 \mathrm{~cm}^{3} \cdot \mathrm{g}^{-1}$ at standard temperature and pressure. In observing that the two branches of a loop cannot satisfy the requirement of thermodynamic reversibility, this means that some distinctive metastable states exist in the process of adsorption and desorption of the adsorbate.

The adsorption capacity of the synthesized zeolites was further explicated using a $t$-plot, which indicated an increase in adsorption with increasing pore volume for the BMMZ, while, for the $\mathrm{Z}$ and MZ, the adsorption capacities tend towards equilibrium at higher pore volumes (Fig. 6, $a$ ). The $V_{m i c}$ and $V_{\text {mes }}$ were obtained from the intercepts of the curves with the $y$-axis, with the thickness range from $3.5 \AA$ to $6 \AA$. In addition, the BET and Langmuir surface areas were determined for the 
zeolite materials by measuring the amount of $\mathrm{N}_{2}$ adsorbed at different relative pressures (Fig. 6, $b$ ), and the results are presented in Table 3.

\section{CONCLUSION}

In this study, $\mathrm{Z}$ and $\mathrm{MZ}$ were successfully synthesized by fusion of FA, $\mathrm{NaOH}$, and $\mathrm{Fe}_{3} \mathrm{O}_{4}$ nanoparticles, and subsequently modified with a biosurfactant produced from agrowaste. The optimum ratio of the $\mathrm{Fe}_{3} \mathrm{O}_{4}$ in this composite was found to have significant effects on the adsorptive capacity of the synthesized zeolites. The combination of the precursor that gave the highest adsorption was found to be 1:1.5:0.3 (in grams) for $\mathrm{FA}, \mathrm{NaOH}$, and $\mathrm{Fe}_{2} \mathrm{O}_{3}$, respectively. The elemental composition by EDS of the synthesized $\mathrm{Z}$ showed that zeolite $\mathrm{X}$ was produced based on the $\mathrm{Si} / \mathrm{Al}$ classification by the International Zeolite Association. The micrographs revealed the zeolite $\mathrm{X}$ and the biosurfactantmodified magnetic zeolite as nanocubes, while the MZ showed aggregated irregular surfaces with crevices at the surface. The FTIR analysis signified asymmetric and symmetric stretching vibrations of $\mathrm{O}-\mathrm{H}$ and internal tetrahedron vibrations of $\mathrm{Si}-\mathrm{O}$ and $\mathrm{Al}-\mathrm{O}$. TGA showed about $20 \%$ loss in the weight of the zeolites, over a temperature range of 22 to $795^{\circ} \mathrm{C}$, that occurred in two stages-the evaporation of the more volatile fractions (often the $\mathrm{OH}^{-}$condensate), followed by the evaporation of the strongly adsorbed and less volatile fractions (usually occluded hydrocarbon compounds). The BET surface area for FA, Z, $\mathrm{MZ}$ and BMMZ were unexpectedly low, being the highest for BMMZ $\left(28.68 \mathrm{~m}^{2} \cdot \mathrm{g}^{-1}\right)$. However, it is remarkable to note that the modification of $\mathrm{Z}$ with biosurfactant increased the $\mathrm{Z}$ surface area by $56.2 \%$. Consequently, the improved properties of the zeolites after modification compared with the precursors suggested that $\mathrm{Z}, \mathrm{MZ}$ and BMMZ would be effective for the removal of organic pollutants.

\section{ACKNOWLEDGEMENT}

This research was partly funded by the Cape Peninsula University of Technology, South Africa. Amodu O. S. wishes to thank the Nigerian Government through the Tertiary Education Trust Fund (TETfund) for the financial support provided during this study. Ojumu T. V. acknowledged the funding support from National Research Foundation (NRF) for this project.

\section{CONFLICT OF INTEREST}

Authors declare that there is no conflict of interest regarding the publication of this paper. 


\section{REFERENCES}

1. A. Feliczak-Guzik, Micropor. Mesopor. Mater., 259: 33 (2017).

2. A. A. Mahabadi, M. Hajabbasi, H. Khademi, and H. Kazemian, Geoderma, 137: 388 (2007).

3. M. Khalid, G. Joly, A. Renaud, and P. Magnoux, Ind. Eng. Chem. Res., 43: 5275 (2004).

4. C. F. Chang, C. Y. Chang, K. H. Chen, W. T. Tsai, J. L. Shie, and Y. H. Chen, J. Colloid Interface Sci., 277: 29 (2004).

5. E. M. Ö. Kaya, A. S. Özcan, Ö. Gök, and A. Özcan, Adsorption, 19: 879 (2013).

6. $\quad$ S. Wang and Y. Peng, Chem. Eng. J., 156: 11 (2010).

7. I. Ali, M. Asim, and T.A. Khan, J. Environ. Manage., 113: 170 (2012).

8. D. Sun, X. Zhang, Y. Wu, and X. Liu, J. Hazard. Mater., 181: 335 (2010).

9. D. Fungaro, M. Yamaura, and T. Carvalho, Journal of Atomic and Molecular Sciences, 2: 305 (2011).

10. D. A. Fungaro and C. P. Magdalena, Environ. Ecol. Res., 2, No. 2: 97 (2014).

11. J. A. Simpson and R. S. Bowman, J. Contam. Hydrol., 108: 1 (2009).

12. Y. Park, G. A. Ayoko, and R. L. Frost, J. Colloid Interface Sci., 354: 292 (2011).

13. Ö. Gök, A. S. Özcan, and A. Özcan, Desalination, 220: 96 (2008).

14. Y. H. Shen, Chemosphere, 44: 989 (2001).

15. C. B. Vidal, G. S. C. Raulino, A. D. da Luz, C. da Luz, R. F. do Nascimento, and D. de Keukeleire, J. Chem. Eng. Data, 59, No. 2: 282 (2013).

16. Y. Dong, D. Wu, X. Chen, and Y. Lin, J. Colloid Interface Sci., 348: 585 (2010).

17. J. Lin, Y. Zhan, Z. Zhu, and Y. Xing, J. Hazard. Mater., 193: 102 (2011).

18. J. Schick, P. Caullet, J. L. Paillaud, J. Patarin, and C. Mangold-Callarec, Micropor. Mesopor. Mater., 142: 549 (2011).

19. T. Anirudhan and M. Ramachandran, Process Saf. Environ., 95: 215 (2015).

20. O. S. Amodu, S. K. Ntwampe, and T. V. Ojumu, BioResources, 9: 3508 (2014).

21. D. Mainganye, T. V. Ojumu, and L. Petrik, Materials, 6: 2074 (2013).

22. N. M. Musyoka, L. F. Petrik, W. M. Gitari, G. Balfour, and E. Hums, J. Environ. Sci. Health Part A, 47: 337 (2012).

23. C. D. Williams and C. L. Roberts, Fuel, 88: 1403 (2009).

24. N. M. Musyoka, L. F. Petrik, E. Hums, A. Kuhnt, and W. Schwieger, Res. Chem. Intermed., 41: 575 (2015).

25. D. Verboekend, N. Nuttens, R. Locus, J. Van Aelst, P. Verolme, J. C. Groen, J. Pérez-Ramírez, and B. F. Sels, Chem. Soc. Rev., 45: 3331 (2016).

26. M. Rivera-Garza, M. Olguın, I. Garcıa-Sosa, D. Alcántara, and G. RodriguezFuentes, Micropor. Mesopor. Mater., 39: 431 (2000).

27. Z. Liu, C. Shi, D. Wu, S. He, and B. Ren, J. Nanotechnol., doi:10.1155/2016/1486107 (2016).

28. P. Chang and Z. Qin, Int. J. Electrochem. Sci., 12, No. 3: 1846 (2017). 